\title{
Media Representation of China’s Policy in US Media Coverage of South China Sea Dispute: A Semantic Prosody Analysis
}

\author{
ZHANG Dan \\ Hainan University, Danzhou, China \\ WANG Qian \\ Northwestern Polytechnical University, Xi’an, China
}

\begin{abstract}
This study examines the representation of China's policy in the media reporting of the South China Sea dispute in The New York Times and The Washington Post by investigating the semantic prosody of the term "China" with a corpus-based approach. The analysis of collocates of China, namely "claim, action, disputes" in the co-text of concordances indicates that media representation of China in US news coverage is associated with negative semantic prosodies that revolve around China's territorial claims, island construction, and resolution of the dispute. This reveals that the stance of news report is influenced by its social, cultural, and political context.
\end{abstract}

Keywords: South China Sea dispute, media representation, corpus linguistics, semantic prosody

\section{Introduction}

Originated in the 1970s, the South China Sea dispute has become the most sensitive and hottest issue in recent years with the change of international relations. More than 20 countries are involved in the dispute, arguing over rich natural resources and important geographical strategic locations in the South China Sea region. The news media around the globe put the spotlight on the development of South China Sea dispute, especially the relationship between China and some Southeast Asian countries, such as Vietnam, Philippines, etc. Although news reporting is required to be objective and authentic, some news reports tend to deliberately emphasize some carefully selected "facts" and implicitly convey the prejudice ideology in the news text driven by various interest-based relationships or different ideologies. In this sense, media discourse has the capacity to influence and control the thoughts of audience to some extent (Van Dijk, 1996), and even mislead them in an implicit way to understand this issue. Similarly, the news reporting of South China Sea dispute also plays a key role in influencing and shaping the knowledge and attitude of international communities towards this hot issue.

This study intends to investigate the semantic prosody of the term "China" in US news reporting of the South China Sea with a corpus-based methodology, aiming to examine how China is represented in the reporting.

Acknowledgement: This study is supported by Philosophical and Social Science Project of Hainan Province "A Study of China's National Image Based on the Analysis of News Report on South China Sea” (Grant No. HNSK(QN) 16-131), Teaching Reform Project of NWPU 2018, and Higher Education Research Fund of NWPU (G2018KY0207).

ZHANG Dan, MA, lecturer, Institute of Tropical Agriculture and Forestry, Hainan University, Danzhou, China.

WANG Qian, MA, Associate Professor, School of Foreign Studies, Northwestern Polytechnical University, Xi'an, China. 


\section{Literature Review}

Semantic prosody refers to "a form of meaning which is established through the proximity of a consistent series of collocates” (Louw, 2000, p. 56), ranging over several units or combinations of words (Sinclair, 2003), just as Partington defined the semantic prosody as "the spread of the connotative color beyond the boundaries of words" (1998, p. 68). Semantic prosody has the attitudinal function for expressing the attitude or evaluation of the speaker/author (Louw, 1993). It is "on the pragmatic side of the semantics/pragmatics continuum" (Sinclair, 2004, p. 34).

Semantic prosody should not be confused with semantic preferences, since they are two different yet interdependent terms. On the one hand, semantic preference refers to the tendency of node word to co-occur with a class of words that share similar semantic features (Stubbs, 2001), while semantic prosody, structured on levels of abstraction, refers to evaluative prosodic patterns that build up over wider stretches of texts (Partington, 2004). Semantic prosody can be seen as a feature of node words, while semantic preference is a feature of collocations. On the other hand, their interdependence lies in semantic preference "contributes powerfully" to building semantic prosody, while semantic prosody "dictates the general environment which constrains the preferential choices of the node item" (Partington, 2004, p. 151). The evaluative connotations related to certain words or phrases can be identified through the analysis of semantic preference and semantic prosody.

Methodologically speaking, semantic prosody should be explored through corpus analysis techniques because it allows us to see how co-occurrences of certain words produce special meanings related to preferences and evaluation (Sinclair, 2003). The positive or negative value of a particular word can be identified via the observation of a large number of textual data. Consequently, the use of corpus-analytical approach in this study is fundamental to reveal the semantic prosody associated with China as represented in the US media reporting of the South China Sea dispute.

\section{Methodology}

\section{Description of the Corpus}

The corpus is compiled based on 110 news reports about South China Sea dispute from two well-known US newspapers: The New York Times and The Washington Post. The reports are retrieved from LexisNexis, online newspaper database with the searching words "South China Sea" or "South Sea". The selecting criteria are that South China Sea is the primary topic rather than the passing words in the text. The whole South China Sea (SCS) corpus contains a total of 107,960 words, covering a time span from January 2012 to May 2017.

\section{Corpus Analysis}

The corpus software AntConc is used to generate collocations and concordance lines, allowing us to focus on specific parts in SCS corpus. Collocation refers to co-occurrence of two words, with a word's collocates as indicators of its semantic prosody, namely attitudinal, evaluative meaning. Since the aim of this study is to investigate media representations of China's image in the reporting of South China Sea dispute, "China" is chosen as the node word to retrieve its collocations and concordance lines. In order to determine the collocational strength of word "China”, frequency and MI (mutual information) are taken into investigation in this study. It is known that the setting of minimum co-occurrence frequency can partly offset the drawback of MI, since MI may overvalue the infrequent words unduly. Within the span of four words to the left and four 
words to the right, the collocates of "China" are identified with a minimum co-occurrence frequency of 3 and a minimal MI score of 3 (Baker, 2006). Concordance lines that show the co-occurrence of certain word in the context are examined in the further analysis with an intention to identify semantic preference and semantic prosody of the words.

\section{Discussion of Findings}

The study starts with an investigation of a list of words that co-occur with "China", within the span of four words on either side. After manually removing functional words and items with a combined frequency below 3 and an MI score below 3.0, the top 10 high collocates for "China" is shown in Table 1, ranked by decreasing MI value. It is worth noting that in the column of co-occurrence frequency, inflected forms of the same word that is plural, -s singular third person or past tense are counted into the total number. For example, in Table 1 the different forms of "claim", namely claims, claimed, are counted to get the total co-occurrence of "China" and "claim".

Table 1

The Top 10 Collocates of "China" in SCS Corpus

\begin{tabular}{ccc}
\hline Collocates & Co-occurrence Frequency & MI \\
\hline Actions & 54 & 4.86091 \\
Claims & 185 & 4.67229 \\
Disputes & 86 & 4.15437 \\
Sovereignty & 53 & 3.97721 \\
Policy & 44 & 3.94138 \\
Territorial & 47 & 3.80387 \\
Power & 34 & 3.64341 \\
Xi & 36 & 3.57008 \\
Islands & 98 & 3.52781 \\
Vietnam & 70 & 3.17382 \\
\hline
\end{tabular}

It can be seen from Table 1 that in the SCS corpus US focuses on China's actions, claims, policy, and power in the news reporting of South China Sea dispute. In addition, the collocates "Vietnam, disputes, sovereignty, territorial, islands" also suggest that South China Sea dispute mainly revolves around the territorial and island disputes between China and other countries, e.g., Vietnam. As can be observed, all the collocations display no negative evaluative meaning. To examine the semantic prosody of "China" in the reporting, in the next section, the first three collocates "actions, claims, disputes" with MI value 4.86091, 4.67229, and 4.15437 respectively will be analyzed in more details with their co-selection patterns through the investigation of the concordance lines.

\section{Semantic Prosody of "Claim” in SCS Corpus}

An investigation of 185 concordance lines of "claim" in SCS corpus reveal that the collocates mainly fall into three semantic preference (see Table 2), namely "the extent of claims", "the nature of claims", and "processes of doing towards claims".

To begin with, when claim has the semantic preference of "the extent of claims", the claims are mainly co-selected with numbers or words denoting degree or extent, such as "much of..., 80\%, 90\%, almost as its own, exclusive, the vast majority of", which emphasizes China's claim is excessive or aggressive. Moreover, the close examination of concordance lines shows that claims are always co-selected with "artificial island", 
"military construction”, "trading routes”, presenting China's claim as illegal with an aim to militarize the South China Sea region. It can be seen from Example 1 that although other claimants have taken many actions in the dispute, China has been portrayed as a troublemaker who bullies the small countries, and aggravates regional tensions with the use of words "rile, boldest".

Example 1: In choosing to rile Vietnam now, one of its best friends in the region, China was making its boldest stance so far in the South China Sea, one of the world's busiest trading routes, and which China claims as almost all its own, experts said. (International NY Times, 2015, 5)

Table 2

Sample Concordance Lines for Claims

\begin{tabular}{|c|c|c|c|}
\hline 1 & near the coasts of Taiwan and Japan. & China claims & the South China Sea as its own despite objections \\
\hline 2 & ruling is expected sometime next year. For its part, & China claims & about 80 percent of the South China Sea, a vital waterway \\
\hline 3 & varying claims are a point of conflict for the region. & China claims & the vast majority of the South China Sea, and it has been \\
\hline 4 & China's reclamation in the disputed South China Sea. & China claims & 90 percent of the South China Sea, which is believed to be \\
\hline 5 & exercises with South Korea in the Yellow Sea, which & China claims & as its exclusive military operations zone. The United State \\
\hline 6 & II, who initiated the case. In repudiating China's & sweeping claims & over the South China Sea, the tribunal handed the \\
\hline 7 & international tribunal considering a challenge to its & expansive claims & in the South China Sea, arguing that the panel has no \\
\hline 8 & on has challenged what it calls China's excessive & laims & in the sea by sailing warships close to the artificial \\
\hline 9 & main purpose: to stand up to China's increasingly & aggressive claims & on the South China Sea, where in recent months, that \\
\hline 10 & multilateral negotiations tends to be drowned out by & bold claims & of China, which considers Taiwan part of its territory and \\
\hline 11 & other issues that arose after the tribunal rebuked & China's claims & over the waters on July 12 . The landmark decision rejected \\
\hline 12 & took office. The United States does not recognize & China’s claims & of sovereignty over the 12 nautical miles surrounding the \\
\hline 13 & A day after an international tribunal rejected & China's claims & in the South China Sea, Beijing excoriated the panel and \\
\hline 14 & An international tribunal invalidated many of & China's claims & in the sea last year, but Chinese leaders have pressed \\
\hline 15 & code of conduct to help nations peacefully address & competing claims & while suggesting that China was in no hurry to have this \\
\hline 16 & of force by any claimant attempting to enforce & disputed claims & in the South China Sea. The statement is clearly aimed at \\
\hline 17 & in destabilizing, unilateral actions asserting & its claims & in the South China Sea. The Philippines has protested \\
\hline 18 & The two moves appeared designed to reinforce & Beijing's claims & over the South China Sea a week after a meeting of foreign \\
\hline
\end{tabular}

Concordance lines show the evaluations of claim as "aggressive, competing, bold, conflicting, excessive" (Table 2: 6-10) provide strong evidence for the semantic preference of "the nature of China's claim". In these cases, China's claims are presented as "undesirable" that need to be challenged and rejected. Adjectives with neutral meaning to co-select with claims include "sovereignty, territorial, historical". However, they seem to carry a distinctly negative evaluative meaning in the context of concordance lines. As can be seen in Example 2, emphasis on China's island construction, militarization seems to project China's actions as the reason for escalation of disputes, meanwhile delegitimizing China's historic claims in the region.

Example 2: The reef, which China has built into an artificial island with an airfield, was in international waters and was not entitled to a 12-mile territorial claim. China's extensive island construction could bolster it militarily in the strategic waterway, something that has unnerved countries in the region. (NY Times, 2015, 11)

Additionally, regarding the semantic preferences of "process of doing towards the claims", the frequent co-selections with claims are realized by the verbs denoting actions. More specifically, when the United States, the Philippines or the international court of justice are in the agent role of taking actions, they "reject, invalidate, ignore, defend, challenge" China's claims (Table 2: 11-14). Consequently, China is represented as the country that finds little support with unjust claims, since international communities do not accept or refuse 
to recognize China's unreasonable claims. However, when China is the agent of "process of doing", the positive verbs that are co-selected with claim, such as "reinforce, solidify, support, enforce, mark, act on" demonstrate negative connotations in the context (Table 2: 16-18) to emphasize China's invasive behaviors towards other claimants, as seen in Example 3:

Example 3: China has now settled on a sustained policy of aggressive actions to support its claims, especially in the South China Sea. (International NY Times, 2015, 10)

\section{Semantic Prosody of “Actions” in SCS Corpus}

An examination of 54 concordance lines of "action/actions" shows that neutral or positive verb expressions ( $71 \%$ of the instances) that are co-selected with actions serve to convey the consequence of actions (e.g. bring...together, generate, indicate, change). There is a cause and effect relationship in which China's actions lead to "fear, security, change of landscape, tension" (Table 3: 5-7) in the dispute. In Example 4, "bring...together" may seem to be positive when standing alone, while the co-selection patterns, such as "artificial islands, military structures, alarm, increase demand" create a negative semantic prosody of "China's actions cause the military alliance of other claimants", through which US's intervention into the dispute as a third party is legitimized.

Example 4: China's efforts to create artificial islands and build military structures on reefs and other outcroppings have alarmed the Philippines, a close American ally, and other countries, like Vietnam and Malaysia. “China's actions are bringing countries in the region together in new ways. And they're increasing demand for American engagement. (NY Times, 2015, 5)

Table 3

Sample Concordance Lines for Actions

$\begin{array}{lrcl}1 & \text { parties in the South China Sea to avoid } & \text { actions } & \text { that raise tensions, said Capt. Jeff } \\ 2 & \text { during the past week, Mr. Carter cited } & \text { China's actions } & \text { as the driving force behind tensions } \\ 3 & \text { U.S. State Department criticized } & \text { China's actions } & \text { Beijing immediately accused } \\ 4 & \text { with other countries that oppose } & \text { China's actions } & \text { in the South China Sea. The ruling } \\ 5 & \text { like Vietnam and Malaysia. China's } & \text { actions are } & \text { bringing countries in the region together } \\ 6 & \text { States Pacific Command, warned that } & \text { China's actions } & \text { were changing the operational landscape } \\ 7 & \text { the South China Sea, declaring that } & \text { such actions } & \text { eroding the security of one of the world's } \\ 8 & \text { condemning China's destabilizing, } & \text { unilateral actions } & \text { in the South China Sea-Beijing is } \\ 9 & \text { fear and anger that China's aggressive } & \text { actions have } & \text { generated among its maritime neighbors, }\end{array}$

While China's actions are constructed as the main factor for the tension in the dispute, China is portrayed as the out-groups that are condemned (e.g., avoid, criticize, condemn, oppose, monitor, not condone) (Table 3 : 1-4) by the in-groups (e.g., US, Philippines, Vietnam, international tribunal etc.). Another strategy for legitimizing US' intervention into the dispute is by attributing their actions or responses towards China's actions to the external parties. This is very evident in Example 5 where the journalist uses an external authority (Senator John McCain) to legitimize US’s strong and determined response to China.

Example 5: Senator John McCain, Republican of Arizona, criticized the Obama administration for what he called a failure to provide a "strong and determined U.S. response" to Chinese actions in the South China Sea. "Freedom of the seas and the principles of the rules-based order are not self-enforcing," he said. (NY Times, 2016, 12) 
Further analysis of "what China are condemned for" indicates that the criticism centers on island reef construction, military exercises, and non-participation in South China Sea arbitration cases. In addition, the negative adjective "aggressive, assertive, problematic, provocative, unilateral, military, unacceptable" associated with China's actions all ascribe qualities of hegemony, threat to China where the salience of negative semantic prosody is manifested.

\section{Semantic Prosody of "Disputes" in SCS Corpus}

The co-occurrences of "China/Chinese" with "dispute(s)" in 86 instances are found to be mainly collocated with positive or neutral expressions (95\% of the instances). The word "dispute" is seen to be mainly preceded by the verbs (68\% of the instances) and adjective expressions (32\% of the instances), which indicate the semantic preference of "the solution to the dispute". The preposition collocation to the right side of "dispute" shows the countries involved in the dispute. All the syntactic patterns contribute to the semantic preference of "how to resolve different countries' maritime rights and territorial claims in the South China Sea dispute".

Table 4

Sample Concordance Lines for Dispute

\begin{tabular}{lrll}
\hline 1 & a fresh opportunity to address maritime & disputes & in a peaceful manner. China's ambassador to the \\
2 & a code of conduct for managing & disputes & Asean should draft its own code and challenge \\
3 & a peaceful resolution of all & disputes & it cannot allow China's claims to go unchallenged \\
4 & set up a way to settle the & disputes & peacefully, said Yan Xuetong, a professor of in \\
5 & remained far apart on the continuing & disputes & in the South China Sea. China has laid claim to \\
6 & Amid the seemingly intractable & disputes & over the South China Sea and Syria, \\
7 & China is currently in & disputes & with several of its neighbors, and the Chinese \\
\hline
\end{tabular}

Syntagmatically, dispute is found in the pattern "N. + V. + dispute" in which the noun is prominently realized by institutions, countries, or leaders, such as "scholars, China, Xi Jinping, Philippines, United States etc.", and the verb is realized by the expressions, such as "address, work out, internationalize, find diplomatic solution, offer a durable solution" (Table 4: 1-4), all of which demonstrate the semantic preference of "the roles played by different countries in resolving the South China Sea dispute”.

The close examination of concordance lines reveals a noticeable distinction of semantic prosody in the representations of different parties involved in the dispute. China's role in resolving the South China Sea dispute is mainly co-selected with negative connotations, such as "Asean, decidedly, ruling, hostilities, confrontation, bilateral, ignore", which contribute to the negative prosody of "China firmly rejects the ruling and resolves the dispute through violence and confrontation" as indicated in Example 6:

Example 6: China has ignored the Philippine case, refusing even to send lawyers to argue its side. (NY Times, 2014, 5)

Table 5

The Co-selection of US, Vietnam, and Disputes

\begin{tabular}{rrrr}
\hline 1 & United States favored a peaceful resolution to & disputes & and a halt to land reclamation by any claimant \\
2 & a spokeswoman for Vietnam's Foreign Ministry, said the & disputes & in the sea by peaceful means and \\
3 & country supported the settlement of any & & \\
4 & U.S. will not take sides in & disputes & over sovereignty. \\
\hline
\end{tabular}


In contrast, the positive prosody of "facilitator" is produced for US's role in maintaining international order. It can be seen that "dispute" is always associated with US, Vietnam in the co-selection patterns (see Table 5), such as "peaceful, international law, neutral, lawful, naval exercise, help", which serves to suggest that the United States uses peaceful and legal means to help other claimants resolve the disputes in order to maintain international law and freedom of navigation.

Additionally, the positive prosody "negotiation” can be observed in reporting Philippines and Vietnam's means in resolving the dispute, which is in the co-selection patterns such as "negotiation, multilateral, ally, direct talk", emphasizing that as an ally of the United States, Vietnam and the Philippines hope to address disputes through negotiations and multilateral talks as can be seen in Example 7:

Example 7: Philippines with backing from the United States, have strongly resisted engaging in bilateral talks with China out of concern that they would be bullied by Beijing. They sought multilateral talks instead. (NY Times, 2014, 5)

\section{Conclusion}

This study uses corpus linguistics techniques to analyze the semantic prosody of the term "China" in the media reporting of the South China Sea dispute in The New York Times and The Washington Post. The collocations of "China" on the basis of corpus show that media representation of China in US news coverage is found to be focused on China's territorial claims, island construction, and resolution of the dispute. Through the analysis of collocates of China, namely "claim, action and disputes" in the co-text of concordances, it is shown that China's territorial claim is constructed as excessive and aggressive, criticized by other claimants and international communities with predominant negative evaluative tone. At the same time, China's island construction is represented as the leading factor for change of landscape and tension in the region. As for the representation of different countries' resolution of the dispute, China is often portrayed as violator of international law, in contrast to US, Philippines and Vietnam's efforts to resolve the dispute in a peaceful and legal means through negotiation and multilateral talk.

Media discourse simply cannot provide a view that is completely independent of subjective interpretation of the events; instead, media organizations "tended to build reality in ways consistent with their underlying ideological and political functions (Kuo \& Nakamura, 2005, p. 411). The prevalent use of negative semantic prosody with China in US media coverage of South China Sea dispute may be interpreted as reflecting the ideological differences and conflicts between China and United States, arising from America's foreign policy and national interest in South China Sea region. Discourses don't just reflect ideologies, but also exert power to influence the attitudes and behaviors of the news readers, since it transports knowledge which is the basis for individual and collective action (Wodak, 2009, p. 46). In the US media coverage, representation of China with negative tone may mislead the readers who aren't clear about the facts have a misunderstanding of China's behaviors, while at the same time legitimizing United States' actions in South China Sea. Overall, this study demonstrates that a thorough understanding of attitude of news reports is inseparable from the social, cultural, and political context the discursive practice is embedded in.

\section{References}

Baker, P. (2006). Using corpora in discourse analysis. London: Continuum.

Bradsher, K. (2014, May 13). China and Vietnam at Impasse Over Rig in South China Sea. The New York Times. Retrieved from https://cn.nytimes.com/asia-pacific/20140513/c13vietnam/zh-hant/dual/

Cooper, H. (2016, December 16). U.S. Demands Return of Drone Seized by Chinese Warship. The New York Times. Retrieved 
from https://www.nytimes.com/2016/12/16/us/politics/us-underwater-drone-china.html

Kuo, S. H., \& Nakamura, M. (2005). Translation or transformation? A case study of language and ideology in the Taiwanese press. Discourse \& Society, 16(3), 393-417.

Louw, B. (1993). Irony in the text or insincerity in the writer? The diagnostic potential of semantic prosodies. In M. Baker, G. Francis, and E. Tognini Bonelli (Eds.), Text and technology: In honour of John Sinclair (pp. 157-175). Amsterdam: John Benjamins.

Louw, B. (2000). Contextual prosodic theory: Bringing semantic prosodies to life. In C. Heffer, H. Sauntson, and G. Fox (Eds.), Words in context: A tribute to John Sinclair on his retirement (pp. 48-94). Birmingham: ELR.

Partington, A. (1998). Patterns and meanings: Using corpora for English language research and teaching. Amsterdam: John Benjamins.

Partington, A. (2004). Utterly content in each other's company: Semantic prosody and semantic preference. International Journal of Corpus Linguistics, 9, 131-156.

Perlez, J. (2015, May 10). Beijing sends bold message with move in disputed sea; China says drilling rig will stay, testing resolve of region and Obama. International New York Times. Retrieved from https://global-factiva-com.ezproxy.lb.polyu.edu.hk/redir/default.aspx?P=sa\&an=INHT000020140510ea5a0000c\&cat=a\&ep $=$ ASE

Perlez, J. (2015, October 28). China objects to U.S. Navy 'provocation'. International New York Times. Retrieved from https://global-factiva-com.ezproxy.lb.polyu.edu.hk/redir/default.aspx?P=sa\&an=INHT000020151027ebas0003q\&cat=a\&ep $=\mathrm{ASE}$

Perlez, J. (2015, November 4). Dispute over South China Sea Prompts Asian Officials to Cancel Joint Statement. The New York Times. Retrieved from https://www.nytimes.com/2015/11/04/world/asia/china-wants-no-mention-of-south-seain-statement.html

Rosenberg, M. (2015, May 27). U.S. Rebukes China on Efforts to Build Artificial Islands. The New York Times. Retrieved from https://www.nytimes.com/2015/05/28/world/asia/us-rebukes-china-on-efforts-to-build-artificial-islands.html

Sinclair, J. (2003). Reading concordances. Harlow: Pearson Education.

Sinclair, J. (2004). Trust the text: Language, corpus and discourse. London/New York: Routledge.

Stubbs, M. (2001). Words and phrases: Corpus studies of lexical semantics. Oxford: Blackwell Publishing.

Van Dijk, T. (1996). Discourse, power and access. In C.-R. Caldas-Coulthard and M. Coulthard (Eds.), Texts and practices. Readings in critical discourse analysis (pp. 84-104). London: Routledge.

Wodak, R. (2009). The discourse of politics in action: Politics as usual. London: Palgrave Macmillan. 